\title{
Sosyal Ağların Pazarlama Üzerindeki Etkileri: Instagram Örneği*
}

\section{The Effects of Social Networks on Marketing: Instagram Example}

\author{
Burak Yılmazsoy a,*** \\ ${ }^{a}$ Bilim Uzmanı, Afyon Kocatepe Üniversitesi, Fen Bilimleri Enstitüsü, İnternet ve Bilişim Teknolojileri Yönetimi Bölümü, 03000, Afyonkarahisar/Türkiye. \\ ORCID: 0000-0001-5462-4247
}

\section{MAKALE BILGİSI}

\section{Makale Geçmişi:}

Başvuru tarihi: 08 Mayıs 2018

Düzeltme tarihi: 19 Mayıs 2018

Kabul tarihi: 21 Mayıs 2018

Anahtar Kelimeler:

Sosyal Medya

Instagram

Instagram Pazarlamas1

\section{A R T I CLE INFO}

\section{Article history:}

Received 08 May 2018

Received in revised form 19 May 2018

Accepted 21 May 2018

\section{Keywords:}

Social Media

Instagram

Instagram Marketing
ÖZ

$\mathrm{Bu}$ araştırmada, Instagram sosyal ağının pazarlamaya olan etkilerinin tüketici görüşleri alınarak incelenmesi amaçlanmıştır. Nitel araştırma yöntemiyle desenlenen araştırmada görüşme tekniği kullanılmıştır. Araştırmanın katılımcılarını Instagram sosyal ağına üyeliği bulunan ve en az 1 defa bu ortamda alışveriş deneyimi olan 41 kullanıcı oluşmaktadır. Veri toplama aracı olarak yarı yapılandırılmış görüşme formu kullanılmıştır. Form Google Doc altyapısıyla çevrimiçi olarak uygulanmıştır. Veriler içerik ve betimsel analiz teknikleri ile analiz edilmiştir. Araştırma sonucunda; katılımcıların gün içinde Instagrama ortalama kez giriş yaptığı, işletmelerin sayfalarını takip etme nedenlerinin neler olduğu, kullanıcıların hangi ürünleri aldıkları, ürün almalarını etkileyen durumların neler olduğu, pazarlama üzerindeki etkileri, Instagram üzerinden alışveriş yapmanın olumlu ve olumsuz yönleri ve işletmelere olan faydalarının neler olduğu sonuçlarına ulaşılmıştır.

\section{A B S T R A C T}

In this research, it is aimed to examine the effect of Instagram social network on marketing by taking the opinions of the consumers. Interview technique was used in the research designed by qualitative research method. The participants of the survey consisted of 41 users who were members of the Instagram social network and had at least one experience shopping in this environment. Semistructured interview form was used as data collection tool. The form was implemented online with Google Docs infrastructure. The data were analyzed with content and descriptive analysis techniques. As a result of the research; how many times the participants log in Instagram, what the reasons of following business pages are, , what products they buy, what conditions affect their purchasing, what the positive and negative aspects of shopping through Instagram are and what benefits the businesses reach through this shopping were all determined.

\section{Giriş}

Teknolojideki gelişim süreci insanların yaşayışlarını etkilemiş ve değişikliklere neden olmuştur. İnternet ve internet teknolojileri insanların yaşayışlarını kolaylaşmış, ulaşılmak istenilen bilgi ve ürünlere ulaşımı hızlanmıştır. Sosyal ağlar eğitim, sağlık, pazarlama gibi birçok alanda kullanılmakta ve büyük faydalar sağlamaktadır. İnternet sayesinde video, müzik, fotoğraf gibi farklı türde veri paylaşımlarının anlık gerçekleştirilmesi ve bilgiye ulaşım daha kolay hale gelmiştir (Y1lmazsoy ve Kahraman, 2017).
Sosyal medya ile ilgili literatür incelendiğinde farklı tanımları olduğu görülmektedir. Bunlardan bazıları;

(i) Köksal ve Özdemir'e (2013) göre “Katılımcılarının çevrimiçi ortamlarda kendilerini ifade etme, iletişime geçme, gruplara katılma ve bu ortamlara fikir, yorum ve yayınlarıyla katkıda bulunma imkânı sağlayan sosyal içerikli web siteleri”,

(ii) Vural ve Bat'a (2010) göre “Telekomünikasyon ve sosyal iletişimin, metin, görsel ve ses içerikli web teknolojileri ile sağlandığı, bu yolla insanların fikirlerini, tecrübelerini paylaştı̆̆

\footnotetext{
* Bu çalışma, 19-21 Nisan 2018 tarihlerinde Denizli’de düzenlenen I. Uluslararası Genç Ekonomistler Öğrenci Kongresi’nde bildiri olarak sunulmuştur.

** Sorumlu yazar/Corresponding author.

e-posta: burakyilmazsoy@hotmail.com
} 
paylaşımlarında bulunduğu çevrimiçi medyanın en yeni türü”,

(iii) Kaplan ve Haenlein'ın (2010) tanımına göre "Web 2.0 üzerinde ideolojik ve teknolojik içeriklerin, yapılanmaların kullanıcı merkezli bir şekilde üretilmesine ve geliştirilmesine izin veren internet tabanlı uygulamaların bütünü’,

(iv) Hazar (2011), insanların sosyalleşme, kaçış, bilgilenme, eğlenme, iletişim, vakit geçirme gibi isteklerine etkileşim boyutuyla cevap veren günümüzde insanları en hızlı ve en fazla kuşatan, kişiselleşebildiği oranda da gelecek vadeden bir araç,

(v) Tiryakioğlu ve Erzurum (2011) sosyal ağları, iletişimin ve sosyal ilişkilerin kurulabildiği, kişilerin, fikirleri, etkinlikleri ve ilgi alanları gibi kişisel bilgilerini kendi ağlarıyla paylaşma imkânı sunan bir çevrimiçi servis,

(vi) Bartlett-Bragg (2006), sosyal ağları grup etkileşiminin gerçekleştiği, işbirlikçi yapıdaki paylaşılan alanı ve sosyal iletişimi arttıran, web ortamında bilgi değişimini kümeleyen uygulamalar bütünü olarak tanımlamışlardır.

Solomon (2013), sosyal medyayı müşterilerin işletmelerle iletişiminin değişen yüzü olarak tanımlarken, Peelen ve Beltman (2013)'da, müşteri ilişkileri yönetiminin geleceğinde sosyal medyanın yerinin önemine vurgu yapmaktadırlar. İnternetin hem bireylerin hem işletmelerin hayatının ayrılmaz parçası haline dönüşmesi ile özellikle elektronik ticaret daha fazla değer kazanmaya başlamıştır (Yaşa Özeltürkay, Bozyiğit ve Gülmez, 2017). Yüksek iletişim ve etkileşime imkân veren sosyal ağların pazarlama alanında kullanılmasıyla ağda yer alan diğer kullanıcılarla paylaşımlarını gerçekleştirebilmekte ve geniş kitlelere ulaşabilmelerini sağlamaktadır. İşletmeler düşük bütçe ile fiziksel ortamda ulaşabileceği sayının çok çok üstünde müşteri adayına ulaşabilmekte, ticari faaliyetlerini genişletebilmektedir.

İşletmeler için sosyal ağlar bir tanıtım aracı olarak kullanılmakta, reklam faaliyetlerini geleneksel medya yerine, yeni medya yani sosyal ağlar üzerinden gerçekleştirmektedirler. İşletmeler sosyal medyaya çevrimiçi pazarın diğer türlerine oranla daha fazla yatırım yapmaktadırlar. Araştırmalara göre, 2008 yılında 455 Milyon Dolar olan sosyal medya harcamalarının (Horovitz, 2009'dan aktaran Kara, 2012: 114) 2018 yılı için 35 Milyar Doların üzerinde olacağı tahmin edilmektedir.

\subsection{Pazarlamanın Gelișim Süreci}

Pazarlamanın gelişim süreci incelendiğinde 1850'li yılarda ürün kıtlığının söz konusu olduğu, tüketicilerin istek ve ihtiyaçlarının göz önüne alınmadığı üretim odaklı pazarlama anlayışı, 1900'lü yıllarda üretimin değil, satışın işletmeler için önemli olduğu satış odaklı pazarlama dönemi, 1950'li yıllarda rekabete dayalı, işletmelerin pazardaki diğer işlemelerle rekabet odaklı pazarlama faaliyetlerini gerçekleştirdiği dönem ve 1990'lı yıllarda müşteri istekleri ve görüşlerinin ön planda olduğu müşteri odaklı pazarlama faaliyetlerinin yapıldığı dönem olarak tanımlanabilir.
Şekil 1. Pazarlamanın Geçirdiği Dönemler

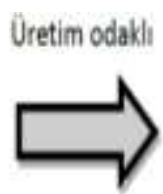

1850

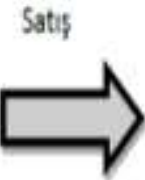

1900

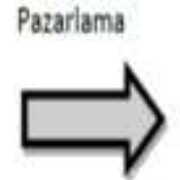

1950

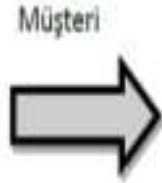

1990
Kaynak: Bose (2002)

Pazarlamada yaşanan bu değişimler, teknolojik gelişmeler ve internetin yaygınlaşması, küreselleşme ve tüketicinin eğitim ve iletişim düzeyindeki artış sebebiyle yaşanmıştır (Özdemir ve Çetinkaya, 2014). Pazarlama alanında yaşanan bu gelişmeler pazarlamanın yapısını, pazarlama karmasını ve tanımını değiştirmiştir. Değişim sürecinde, ilişki pazarlaması gelişmiş, müşteri işletmenin odak noktasına koyulmuş, değer üretme ve değer aktarma kavramları gelişmiş ve pazar yönelimlilik esas hale gelmiştir (Albay, 2010).

Bilişim ve iletişim teknolojilerindeki gelişim, yaygınlaşma ve ucuzlama, tüketicinin gerek pazar içerisinde gerekse de kendi aralarındaki iletişimin artmasına neden olmaktadır (Çetinkaya ve Özdemir, 2014). Yeni pazarlama yaklaşımında işletmeler müşterileri ile ilgili bilgi toplama, depolama, işleme ve dağıtma gibi işlevlerin yapılması teknoloji ile mümkün hale gelmiştir (Albay, 2010). Günümüzde dünyanın başka bir ülkesinden dahi internet üzerinden alışveriş yapılabilmektedir. İşletmelerde uzaklık fark etmeksizin ticari faaliyetlerini gerçekleştirebilmekte, web teknolojilerindeki gelişimle birlikte sosyal ağları aktif kullanarak pazarlama faaliyetlerini bu ortamlarda devam ettirmektedirler.

\subsection{Pazarlamada Dönüşüm - Sosyal Medya Pazarlamacillı̆ 1}

Radyo, televizyon gazete gibi geleneksel medya araçları ile işletmelerin reklam ve pazarlama faaliyetleri gerçekleştirilmekteydi. Pazarlamanın birinci periyodunda geleneksel medya ile pazarlama faaliyetleri ve tanıtım yapılmaktayken tek yönlü, tüketicilerin görüşlerinin dikkate alınamadığı tekdüze bir faaliyet yapılmaktayd. Pazarlamanın ikinci periyodunda ise doğrudan posta, tele pazarlama ve kataloglar yoluyla doğrudan pazarlama faaliyetlerinin (Özdemir ve Çetinkaya, 2014) yapıldığı dönem olmuştur. Pazarlamanın ikinci periyodu, sosyal web çağının yaşandığı günümüzde (Özdemir ve Çetinkaya, 2014) tüketicilerin daha aktif olduğu, sosyal ağların aktif kullanıldığı ve ürene ulaşımın kolaylaştığı pazarlama ortamidir.

$\mathrm{Bu}$ noktada eski pazarlamadan sosyal webin yeni pazarlamasına geçişin sağlanabilmesi için öncelikle pazarlama anlayışının, daha sonra marka değeri, bölümleme, hedefleme, iletişim, içerik, viral olma, görüşler, yayımcı ve reklamcının rolü, bilgi hiyerarşisi ve kaçınılmaz olarak ödemelerin değişmesi gerekmektedir (Weber, 2007: 3334'den aktaran Akar, 2010: 10). 
Tablo 1. Geleneksel Pazarlamadan Sosyal Medya Pazarlamaya Geçiş

\begin{tabular}{|c|c|c|}
\hline Bileşenler & Geleneksel Pazarlama & Yeni Pazarlama \\
\hline Pazarlama anlayışı & Markayı anlatan tek yönlü, tek taraflı iletişim. & $\begin{array}{l}\text { İlişki ve diyalogları beslemek, daha şeffaf olma, güven } \\
\text { kazanma, inanılırlık yaratma. }\end{array}$ \\
\hline Marka değeri & Marka hatırlatmaları önemlidir. & $\begin{array}{l}\text { Marka değeri müşteriler tarafindan belirlenir: Müşteriler, } \\
\text { mal ya da hizmeti ne derecede önermektedir? }\end{array}$ \\
\hline Bölümleme & Demografiye göre müşteri grupları. & $\begin{array}{l}\text { İlgi, tutum, davranışa göre müşteri grupları: Müşteriler için } \\
\text { ne önemli? }\end{array}$ \\
\hline Hedefleme & $\begin{array}{l}\text { Demografiye göre hedefleme, özellikle medya satın } \\
\text { almaları. }\end{array}$ & Müşteri davranışına göre hedefleme. \\
\hline İletişim & $\begin{array}{l}\text { Radyo-televizyon yayımı stil: Müşterinin } \\
\text { özümsemesi için zorla iletilen ve yaratılan mesaj. }\end{array}$ & $\begin{array}{l}\text { Diyalog, kişisel görüss, müssteri yorumları ya da arama ve } \\
\text { sorgulama yoluyla interaktif iletişime yarayan dijital çevre. }\end{array}$ \\
\hline İçerik & $\begin{array}{l}\text { Pazarlamacılar tarafindan yaratılan ve kontrol edilen } \\
\text { profesyonel içerik. }\end{array}$ & $\begin{array}{l}\text { Artarak görselleşen profesyonel ve kullanıcı yaratımlı karma } \\
\text { içerik. }\end{array}$ \\
\hline Viral olma & $\begin{array}{l}\text { Güzel ancak içerikten ziyade sıklıkla çarpıcı sunum } \\
\text { yoluyla yönlendirilen popülerlik. }\end{array}$ & $\begin{array}{l}\text { Viral olma, dikkate değer ürünlerle ilgili güvenilir içeriğe ya } \\
\text { da insanların konuşmasını ve e-mail göndermesini } \\
\text { sağlayacak özelliklere dayanmaktadır. }\end{array}$ \\
\hline Görüşler & Uzma & Kullanıc1lar görüş belirtir ve her şeyi oylar. \\
\hline Reklamc1/yay & $\begin{array}{l}\text { Yayımcı kanal kurar ve kanal ya da programlara } \\
\text { sponsor olan reklamcılar için izleyici toplayacak } \\
\text { içeriği kontrol eder. }\end{array}$ & $\begin{array}{l}\text { İçeriğ } \\
\text { nered }\end{array}$ \\
\hline Strateji & $\begin{array}{l}\text { Üst yönetimce uygulanan yukarıdan aşağıya } \\
\text { stratejisi taktikleri belirler. }\end{array}$ & $\begin{array}{l}\text { Aşağıdan yukarıya stratejisi, sürekli testler ve müşteri } \\
\text { girişlerinden toplanan başarılı }\end{array}$ \\
\hline Hiyerarşi & $\begin{array}{l}\text { Bilgi, uygun reklamcılar için kanallar, dosyalar ve } \\
\text { kategoriler içerisinde düzenlenir. }\end{array}$ & $\begin{array}{l}\text { Bilgi uygun kullanıcılar için istenilen anahtar kelime ile elde } \\
\text { edilebilir. }\end{array}$ \\
\hline Ödeme & $\begin{array}{l}\text { Bir reklam kampanyasıyla } 1000 \text { insana ulaşma bedeli } \\
\text { (İngilizce kısaltması CPM): Maliyet üzerine vurgu } \\
\text { yapılmaktadır. Reklamcılar fikir satın alır (söyleme } \\
\text { payı=akı1 payı= pazar payı) }\end{array}$ & $\begin{array}{l}\text { Yatırımların geri dönüşümü (İngilizce kısaltması } \\
\text { ROI):Gelecekteki büyüme için pazarlamaya yatırım } \\
\text { yapmaktadır. Karlılık ölçülebilir geri dönüşümlere dayalıdır. }\end{array}$ \\
\hline
\end{tabular}

Kaynak: Weber'den (2007: 33-34) aktaran: Akar (2010: 31-32).

Tablo 2. Örneklem Grubunun Dağılımı

\begin{tabular}{|c|c|c|c|c|c|}
\hline Katılımcilar & Cinsiyet & Yaş & Eğitim Düzeyi & Aylık Hane Geliri & Meslek \\
\hline K1 & Erkek & 27 & Yüksek Lisans & 4000 & Akademisyen \\
\hline K2 & Kadın & 28 & Lisans & 10000 & Öğretmen \\
\hline K3 & Kadın & 19 & Önlisans & 4000 & Estetisyen \\
\hline K4 & Kadın & 25 & Önlisans & 5000 & Muhasebeci \\
\hline K5 & Kadın & 25 & Önlisans & 5500 & Öğrenci \\
\hline K6 & Kadın & 25 & Lise & 1500 & Ev Hanımı \\
\hline K7 & Kadın & 42 & Yüksek Lisans & 7000 & Bil. Uzmanı \\
\hline K8 & Kadın & 24 & Lisans & 3000 & Sanat Tarihçi \\
\hline K9 & Erkek & 28 & Lisans & 3500 & Muhasebe \\
\hline K10 & Erkek & 22 & Önlisans & 5000 & Polis \\
\hline K11 & Kadın & 22 & Lisans & 600 & Öğrenci \\
\hline K12 & Erkek & 22 & Lisans & 5000 & Öğrenci \\
\hline K13 & Erkek & 28 & Lisans & 2500 & Aşç1 \\
\hline K14 & Kadın & 30 & Lisans & 7000 & Öğretmen \\
\hline K15 & Kadın & 30 & Yüksek Lisans & 10000 & Öğretmen \\
\hline K16 & Erkek & 24 & Yüksek Lisans & 4500 & Öğretmen \\
\hline K17 & Erkek & 44 & Lisans & 5000 & Turizm \\
\hline K18 & Kadın & 26 & Lisans & 2000 & Öğrenci \\
\hline K19 & Erkek & 30 & Lisans & 3000 & Öğretmen \\
\hline K20 & Erkek & 27 & Lisans & 1000 & Muhasebeci \\
\hline K21 & Kadın & 22 & Lisans & 2500 & Öğrenci \\
\hline K22 & Kadın & 23 & Lisans & 4000 & Serbest \\
\hline K23 & Kadın & 21 & Lisans & 1000 & Öğretmen \\
\hline K24 & Erkek & 28 & Yüksek Lisans & 10000 & Mühendis \\
\hline K25 & Kadın & 22 & Lisans & 2500 & Öğrenci \\
\hline
\end{tabular}




\begin{tabular}{|c|c|c|c|c|c|}
\hline K26 & Kadın & 22 & Lisans & 10000 & Öğrenci \\
\hline K27 & Kadın & 22 & Lisans & 2000 & Öğrenci \\
\hline K28 & Kadın & 22 & Lisans & 1500 & Çiftçi \\
\hline K29 & Kadın & 23 & Lisans & 2000 & Öğretmen \\
\hline $\mathrm{K} 30$ & Kadın & 21 & Lisans & 2500 & Öğrenci \\
\hline K31 & Kadın & 23 & Lisans & 5000 & Öğrenci \\
\hline K32 & Kadın & 23 & Lisans & 2000 & Öğrenci \\
\hline K33 & Kadın & 24 & Önlisans & 2800 & Bakıc1 \\
\hline K34 & Erkek & 28 & Yüksek Lisans & 5500 & Mühendis \\
\hline K35 & Erkek & 38 & Lise & 7000 & İK Görevlisi \\
\hline K36 & Kadın & 29 & Yüksek Lisans & 9000 & Akademisyen \\
\hline K37 & Kadın & 28 & Önlisans & 6000 & Memur \\
\hline K38 & Kadın & 30 & Yüksek Lisans & 8500 & Akademisyen \\
\hline K39 & Kadın & 26 & Önlisans & 4000 & İşsiz \\
\hline K40 & Kadın & 26 & Yüksek Lisans & 7000 & Öğrenci \\
\hline K41 & Kadın & 22 & Lisans & 2000 & İşsiz \\
\hline
\end{tabular}

\subsection{Instagram Sosyal A $\breve{g}$ ile Pazarlama}

Sosyal medya vasitası ile yapılan pazarlama faaliyetleri müşteri ilişsileri yönetimi, müşteri hizmetleri, markalama, satın alma araştırmaları, birçok pazarlama faaliyetleri için ehemmiyetli bir kanal olarak görülmekte (Ashley ve Tuten, 2015) ve önemli bir bilgi kaynağ (Xiang ve Gretzel, 2010) olmasının yanında tüketiciler ile sosyal ağlar üzerinden iletişim ve etkileşime geçmenin kurumsal saygınlık kazanılmasına katkı sağlamaktadır (Dijkmans, Kerkhof ve Beukeboom, 2015).

Instagram sosyal ağı son dönemlerde satıcıların ürünleri için pazarlama faaliyetlerini gerçekleştirdiği bir ortam olmuştur. Instagram ile işletmeler ürünlerinin görsellerini ve videolarını paylaşabilmekte, ürün özelliklerini, bilgilerini paylaşarak ilgi alanındaki kitlelere ulaşabilmektedir. Satıcıların etiketleme yöntemiyle paylaşımlar yapmasıyla, kullanıcı ilgi alanındaki ürün için arama yaparak ulaşabilir, diğer kullanıcıların sayfasında paylaşılmasıyla yayılmasını sağlayabilir ve daha geniş alanlara ulaşabilmektedir.

Kullanıcılar ilgi alanlarına giren ürün veya hizmeti satan kişilerin profillerine ulaşarak, ürün bilgilerine, görsellerine ulaşabilmektedir. Ürün görsel ve paylaşımının altında yer alan yorum kısmında tüketiciler ürün hakkında bilgi alabilmek, görüş bildirmek, soru sormak ya da memnuniyetlerini bildirmek için kullanabilmektedir. Instagram, bugün Photoshop'un belirli özelliklerini bedava olarak sunmaktadır. Instagram yoluyla normal bir fotoğraf daha etkili hale getirilebilir ve böylece daha çok ilgi çekerek, daha çok insana ulaşılabilir (Sevinç, 2015).

Küçük işletmelerde pazarlama faaliyetlerini Instagram sosyal ağ1 üzerinden gerçekleştirerek pazar ağını genişletmekte, daha fazla kullanıcıya ulaşmakta ve rekabet edebilir konuma gelebilmektedirler. Sadece küçük işletmeler veya bireyler değil büyük işletmeler de tanıtım kanalı olarak Instagram'1 kullanmakta hatta buraya reklam vermektedir (Yaşa Özeltürkay, Bozyiğit ve Gülmez, 2017). Instagram'ın ilk reklam vereni ise dünyaca ünlü moda markası Michael Kors olmuş ve moda markasının sonsuzluk üzerine kurgulu yeni saat kampanyası için kullandığı Instagram reklamları üç yüz binden fazla kullanıcının etkileşimini yakalamıştır (Ferah, 2013). Sponsorlu paylaşımlar ile mevcut tüketici adaylarına ulaşım kolaylaşmakta ve işletmeler faaliyetlerini genişleterek gelişebilmektedir. Sosyal ağların giderek artan kullanıcı sayısı, gelişen pazarlama faaliyetleri, tanıtım ve ulaşılabilirliği kolaylaştıran yapısının olması bu alandaki faaliyetlerin önemini arttırmakta ve hızla gelişmeye devam eden teknoloji ile değişim devam etmektedir.

\subsection{Araştırmanın Amacı}

Instagram sosyal ağının pazarlamaya olan etkileriyle ilgili araştırma ve istatistiki veriler incelendiğinde; pazarlama faaliyetlerinde kullanımının hızla arttığı görülmektedir. Instagram'ın reklam, ürün tanıtım, iletişim amaçlı kullanımının yüksek olması, tüketicilerin davranışları üzerindeki etkilerin incelenmesi, bu alanda yapılan çalışmaların az olması ve araştırmanın yeni araştırmalara yön vermesi durumu araştırmanın önemini arttırmaktadır.

$\mathrm{Bu}$ çalışmanın amacı, Instagram sosyal ağının pazarlamaya olan etkilerini tüketici görüşlerini alarak incelemektir. Amaç doğrultusunda aşağıdaki sorulara cevap aranmıştır.

(i) Instagram sosyal ağının pazarlamaya olan etkileri nelerdir?

(ii) Instagram sosyal ağından tüketiciler neler satın almaktadir?

(iii) Instagram'da tüketiciler alışveriş yaparken nasıl davranırlar?

(iv) Instagram sosyal ağı üzerinden alışverişin olumlu ve olumsuz yönleri nelerdir?

\section{Yöntem}

\subsection{Araştırma Modeli}

Instagram sosyal ağının pazarlama ve tüketiciler üzerindeki etkilerinin incelendiği bu çalışmada tarama modeli kullanılmıştır. Araştırma deseni olarak olgu bilimden yararlanılan araştırmanın verileri, nitel araştırma veri toplama tekniklerinden biri olan görüşme yoluyla elde edilmiştir (Balc1, 2005: Kuş, 2003: Türnüklü, 2000). 


\subsection{Evren ve Örneklem}

Çalışma grubunu Instagram sosyal ağına üyeliği olan ve en az 1 defa bu ortamda alışveriş deneyimi olan 41 kullanıcı oluşmaktadır. Katılımcıların gönüllülük esası ile doldurduğu form çevrimiçi ortamda uygulanmıştır. Katılımcılara ulaşmak için Instagram sosyal ağı üzerinden satış işlemleri yapan bir işletmenin müşterilerine ulaşılmış ve yüksek üye sayılarına sahip Facebook gruplarında, Google Doc altyapısı ile oluşturulan form paylaşılarak 15 gün süresince veriler toplanmıştır. Görüşme formunu toplam 70 katılımcı doldurmuş, Instagram'dan en az 1 defa alışveriş deneyimi olmayan ve formu hatalı dolduran toplam 29 katilımc1 görüşleri iptal edilerek, 41 katılımcının formu değerlendirmeye alınmıştır.

Çalışmaya katılan katılımcıların cinsiyet, yaş, eğitim düzeyi, aylık hane geliri ve mesleklerine göre dağılımları Tablo 2'de verilmiştir.

\subsection{Veri Toplama Arac1}

Araştırmada, Instagram sosyal ağının pazarlamaya olan etkilerini belirleyebilmek için yarı yapılandırılmış görüşme tekniğinden yararlanılmıştır. Nitel araştırmalarda sıklıkla yararlanılan yarı yapılandırılmış görüşme tekniği kullanılarak, görüşme yapılan kişilerin olay ve olguları anlamlandırmalarını, duygu ve düşüncelerini anlamak ve daha derin bilgi edinmek amaçlanmıştır (Yıldırım ve Şimşek, 2011). Yarı yapılandırılmış görüşme formunun oluşturulmasında öncelikle alanyazın taraması yapılmış (Yaşa Özeltürkay, Bozyiğit ve Gülmez, 2017; Goor, 2012; Kutluğ, 2014; Wally ve Koshy, 2014) ve araştırmanın amacına uygun sorular hazırlanmıştır.

Hazırlanmış olan sorulara ilişkin olarak uzman görüşüne başvurulmuştur. Ardından görüşme formunda yer alacak sorular belirlenerek oluşturulan yarı yapılandırılmış görüşme formu Google Doc altyapısıyla çevrimiçi form haline getirilmiş ve uygulanmıştır. Deneme amaçlı uygulanan yarı yapılandırılmış görüşme formunda bazı soruların net olarak anlaşılmadığ 1 ve amaca uygun olmayan soruların yer aldığ değerlendirilmiştir. Bu sürecin ardından ilgili sorularda, dönütlere göre düzenlemeler yapılmış ve sorular çıkarılarak forma son hali verilmiştir. Yarı yapılandırılmış görüşme formunun son halinde tüketicilerin Instagram sosyal ağ üzerinden gerçekleştirilen pazarlama faaliyetlerine ilişkin neler düşündüklerini belirleme amaçlı olarak 13 soruyu içermektedir.

\subsection{Verilerin Analizi}

Betimsel analizde özetlenen ve yorumlanan veriler, içerik analizinde daha derin bir işleme tabi tutulur ve betimsel bir yaklaşımla fark edilemeyen kavram ve temalar bu analiz sonucu keşfedilebilir. $\mathrm{Bu}$ amaçla toplanan verilerin önce kavramsallaştırılması, daha sonra da ortaya çıkan kavramlara göre mantıklı bir biçimde düzenlenmesi ve buna göre veriyi açıklayan temaların saptanması gerekmektedir. $\mathrm{Bu}$ çerçevede, içerik analizi yoluyla verileri tanımlamaya, verilerin içinde saklı olabilecek gerçekleri ortaya çıkartmaya çalışırız. İçerik analizinde temelde yapılan işlem, birbirine benzeyen verileri belirli kavramlar ve temalar çerçevesinde bir araya getirmek ve bunları okuyucunun anlayabileceği bir biçimde düzenleyerek yorumlamaktır (Yıldırım ve Şimşek, 2005).

Nitel verilerin nicelleştirilmesi; görüşme, gözlem veya dokümanların incelenmesi yoluyla elde edilmiş yazılı biçimde verinin belirli süreçlerden geçirilerek sayılara veya rakamlara dökülmesidir. Sayılar ve rakamlar genellikle nicel araştırma türleriyle anılıyor olsa da, nitel verini bilir bir düzeyde sayılara indirgenmesi mümkündür. Nitel verilerin sayılara indirgenmesindeki amaç, istatistiksel yöntemlere başvurarak genellemeler yapmak veya sınırlı sayıdaki belirli değişkenler arasında ilişki aramak değildir. Zaten, nitel verinin doğası buna izin vermez (Yıldırım ve Şimşek, 2005).

İçerik analizi yapılarak veriler kavramlaştırılarak kodlanmış ve nicel verilere dönüştürülmüştür. Dönüştürülen nitel veriler betimsel istatistik yöntemleriyle yorumlanmıştır. Betimsel istatistik bir değişkene ilişkin sayısal değerlerin toplanması, betimlenmesi ve sunulmasına olanak sağlayan istatistiksel işlemleri tanımlar. Bir örneklem üzerinde ya da ulaşılabilen durumlarda evrenin tamamından gözlem yaparak elde edilen verileri kullanarak, araştırmaya katılan bireylerin ya da objelerin özelliklerini belirlemeyi amaçlayan süreçtir (Büyüköztürk, 2005).

\section{Bulgular ve Yorumlar}

Araştırmanın bu bölümünde toplanan verilerden elde edilen bulgulara yer verilmiştir.

Tablo 3. Instagram Hesabına Ne Kadar Süredir Sahipsiniz? Sorusuna Katılımcıların Vermiş Oldukları Cevapların Dağılımları

\begin{tabular}{lcc}
\hline Kodlar & f & $\%$ \\
\hline 1 yıldan az & 4 & 9,8 \\
$1-3$ yil & 12 & 29,3 \\
$3-5$ y1l & 18 & 43,9 \\
5 y1l ve üzeri & 7 & 17,1 \\
\hline Toplam & 41 & 100,0 \\
\hline
\end{tabular}

Tablo 3'de katılımcıların Instagram sosyal ağı kullanım süreleri için vermiş olduğu cevaplar incelendiğinde katılımcıların \% 43,5'inin ( $\mathrm{f}=18$ ) 3 - 5 yıl arası kullanım süresi, \%29,3'ünün (f=12) 1-3 y1l kullanım süresi, $\% 17,1$ 'inin $(\mathrm{f}=7) 5$ y1l ve üzeri ve $\% 9,8$ 'inin $(\mathrm{f}=7$ ) 1 yıldan az kullanım sağladığı görülmektedir.

Tablo 4. Gün İçerisinde Instagram Hesabınızı Ne Sıklıkla Kontrol Edersiniz? Sorusuna Katılımcıların Vermiş Oldukları Cevapların Dağılımları

\begin{tabular}{lcc}
\hline Kodlar & f & $\%$ \\
\hline $1-5$ & 9 & 21,9 \\
$6-10$ & 18 & 43,9 \\
$11-15$ & 4 & 9,8 \\
$16-20$ & 5 & 12,2 \\
$21-29$ & 3 & 7,3 \\
30 ve üzeri & 2 & 4,9 \\
\hline Toplam & 41 & 100,0 \\
\hline
\end{tabular}

Tablo 4'de katılımcıların Instagram sosyal ağını kontrol etme sıklıklarına ilişkin vermiş olduğu cevaplar incelendiğinde katılımcıların \% 43,9'unun (f=18) 6-10 kez, $\% 21,9$ 'unun (f=9) $1-5 \mathrm{kez}, \% 12,2$ 'sinin $(\mathrm{f}=5) 16-20 \mathrm{kez}$, \%9,8'inin (f=4) 11-15 kez,\%7,3'ünün (f=3) 21-29 kez, 
\%4,9'unun (f=2) 30 kez ve üzeri kontrol sağladığ görülmektedir.

Tablo 5. Instagram'da Bir İşletmenin Sayfasını Takip Etme Nedenleriniz Nelerdir? Sorusuna Katılımcıların Vermiş Olduğu Cevapların Dağılımları

\begin{tabular}{lcc}
\hline Kodlar & $\mathrm{f}$ & $\%$ \\
\hline Ürünleri takip etmek ve satın almak için & 6 & 14,6 \\
Görsel ve paylaşımları ilgi çekici olduğu için & 14 & 34,1 \\
İhtiyaçlarımı karşıladığı ve ilgi alanımda olduğu için & 9 & 22,0 \\
Güvenilir bir alışveriş sayfası olduğu için & 2 & 4,9 \\
Fikir edinmek için (Fiyat, Model) & 5 & 12,2 \\
Ekonomik ürünler olduğu için & 5 & 12,2 \\
\hline Toplam & 41 & 100,0 \\
\hline
\end{tabular}

Tablo 5'de katılımcıların Instagram sosyal ağında yer alan işletme sayfalarını takip etme nedenlerine ilişkin soruya vermiş olduğu cevaplar incelendiğinde; katılımcıların \%34,1'inin (f=14) görsel ve paylaşımları ilgi çekici olduğu için, \%22,0'ının ( $\mathrm{f}=9)$ ihtiyaçlarımı karşıladığı ve ilgi alanımda olduğu için, \%14,6'sının (f=6) ürünleri takip etmek ve satın almak için, \%12,2'sinin ( $\mathrm{f}=5)$ ürün hakkında bilgi edinmek için, \%12,2'sinin ( $\mathrm{f}=5)$ ekonomik ürünler olduğu için ve \%4,9'unun ( $\mathrm{f}=2$ ) güvenilir bir alışveriş sayfası olması görüşlerini bildirdiği görülmektedir.

Tablo 6. Instagram Sosyal Ağından Hangi Ürünleri Aldınız? Sorusuna Katılımcıların Vermiş Olduğu Cevapların Dağılımları

\begin{tabular}{lcc}
\hline Kodlar & $\mathrm{f}$ & $\%$ \\
\hline Hediyelik eşya ve süs & 6 & 14,6 \\
Giyim ürünleri & 14 & 34,1 \\
Elektronik ürünler & 3 & 7,3 \\
Tak1 ürünleri & 7 & 17,1 \\
Ayakkab1 & 9 & 22,0 \\
Kozmetik & 2 & 4,9 \\
\hline Toplam & 41 & 100,0 \\
\hline
\end{tabular}

Tablo 6'da katılımcıların Instagram sosyal ağından hangi ürünleri satın aldıklarına ilişkin soruya vermiş olduğu cevaplar incelendiğinde; katılımcıların \%34,1'inin ( $\mathrm{f}=14$ ) giyim ürünlerini aldığı, \%22,0'ının $(\mathrm{f}=9)$ ayakkabı, $\% 17,1$ 'inin $(\mathrm{f}=7$ ) takı ürünleri, \%14,6'sının ( $\mathrm{f}=6$ ) hediyelik ve süs eşyası, \% 7,3'ünün ( $\mathrm{f}=3$ ) elektronik ürün, \%4,9'unun $(\mathrm{f}=2)$ kozmetik ürünlerini almış oldukları görülmektedir.

Tablo 7. Ürün ve Hesaba İlişkin Durumların Satın Alma Niyetinize Etkisi Ne Düzeydedir? Sorusuna Katılımcıların Vermiş Olduğu Cevapların Dağılımları

\begin{tabular}{lcc}
\hline Kodlar & f & $\%$ \\
\hline Beğeni sayısı & 6 & 14,6 \\
Takipçi sayısı & 8 & 19,5 \\
Yorumlar & 20 & 48,8 \\
Görselliği yüksek paylaşımlar & 4 & 9,8 \\
Etkisi yok & 3 & 7,3 \\
\hline Toplam & 41 & 100,0 \\
\hline
\end{tabular}

Tablo 7'de katılımcıların Instagram üzerinden ürün alma isteklerini etkileyen etkenlere ilişkin soruya vermiş olduğu cevaplar incelendiğinde; katılımcıların \%48,8'inin ( $\mathrm{f}=20$ ) yorumlar, \%19,5'inin ( $\mathrm{f}=8$ ) takipçi sayısı, \%14,6'sının (f=6) beğeni sayısı, \%9,8'inin ( $\mathrm{f}=4$ ) görselliği yüksek paylaşımlar ve $\%$ 7,3'ünün ( $\mathrm{f}=3$ ) etkisinin yok görüşlerini bildirmişlerdir.

Tablo 8. Instagram Sosyal Ağından Ürün Alma Nedenleriniz Nelerdir? Sorusuna Katılımcıların Vermiş Olduğu Cevapların Dağılımları

\begin{tabular}{lcc}
\hline Kodlar & $\mathrm{f}$ & $\%$ \\
\hline Fiyatı uygun ürünler olması & 11 & 26,8 \\
Ürün çeşitliliğinin olması & 9 & 22,0 \\
Alı̧verişin kolay olması & 7 & 17,1 \\
Satıcıya güven duyurulması & 2 & 4,9 \\
Kapıda ödeme olması & 2 & 4,9 \\
Ürünün etkileyici olması & 10 & 24,4 \\
\hline Toplam & 41 & 100,0 \\
\hline
\end{tabular}

Tablo 8'de katılımcıların Instagram üzerinden ürün alma nedenlerine ilişkin soruya vermiş olduğu cevaplar incelendiğinde; katılımcıların \%26,8'inin $(\mathrm{f}=11)$ fiyatı uygun ürünler olması, \%24,4'inin (f=10) ürünün etkileyici olması, \%22,0'sinin (f=9) ürün çeşitliliğinin olması, \%17,1'inin ( $\mathrm{f}=7$ ) alışverişin kolay olması, \%4,9'unun ( $\mathrm{f}=2)$ satıciya güven duyurulması ve $\% 4,9$ 'unun $(\mathrm{f}=2)$ kapıda ödeme olması görüşlerini bildirdiği görülmektedir.

Tablo 9. Instagram'ın Pazarlama Üzerindeki Etkileri Sizce Nedir? Sorusuna Katılımcıların Vermiş Olduğu Cevapların Dağılımları

\begin{tabular}{lcc}
\hline Kodlar & $\mathrm{f}$ & $\%$ \\
\hline Etkili ürün tanıtımları yapılabilmektedir & 11 & 26,8 \\
Kolay ve hızlı alışveriş ortamı sunuyor & 11 & 26,8 \\
Ürün çeşitliliği sağlıyor & 4 & 9,8 \\
Geniş kitlelere ulaşılabiliyor & 7 & 17,1 \\
Sosyal ağ üzerindeki reklamlar çok etkili & 7 & 17,1 \\
Çok etkili olduğunu düşünmüyorum & 1 & 2,4 \\
\hline Toplam & 41 & 100,0 \\
\hline
\end{tabular}

Tablo 9'de katılımcıların Instagram sosyal ağının pazarlama üzerindeki etkilerine ilişkin soruya vermiş olduğu cevaplar incelendiğinde; katılımcıların \%26,8'inin (f=11) etkili ürün tanıtımları yapılabilmektedir, \%26,8'inin $(\mathrm{f}=11)$ kolay ve hızlı alışveriş ortamı sunuy, \%17,1'inin ( $\mathrm{f}=7$ ) geniş kitlelere ulaşılabiliyor, \%17,1'inin $(\mathrm{f}=7)$ sosyal ağ üzerindeki reklamlar çok etkili, \%9,8'i (f=4) ürün çeşitliliği sağlıyor ve \%2,4'ünün ( $\mathrm{f}=1)$ çok etkili olduğunu düşünmüyorum görüşlerini bildirdiği görülmektedir.

Tablo 10. Instagram'da (Küçük) İşletmelerin Pazarlama Faaliyetlerini Nasıl Buluyorsunuz? Sorusuna Katılımcıların Vermiş Olduğu Cevapların Dağılımları

\begin{tabular}{lcc}
\hline Kodlar & f & $\%$ \\
\hline Hedef kitleye kolay ulaşım sağlamaktadırlar & 7 & 17,1 \\
Pazar ağı geniş & 2 & 4,9 \\
Ulaşılabilir olmalarını sağlıyor & 2 & 4,9 \\
Kendilerini geliştirmelerine ve büyümelerine katkı & 8 & 19,5 \\
sağlıyor & & \\
Daha samimi olmaları ve kampanya, çekiliş gibi & 4 & 9,8 \\
etkinliklerle tercih nedeni oluyorlar & 10 & 24,4 \\
Rekabet edebilir duruma geliyorlar & 5 & 12,2 \\
Güven vermiyorlar & 3 & 7,3 \\
Rekabet ortamı yok & 41 & 100,0 \\
\hline Toplam & \multicolumn{2}{c}{} \\
\hline
\end{tabular}

Tablo 10'da katılımcıların Instagram sosyal ağınında küçük işletmelerin pazarlama faaliyetlerine ilişkin soruya vermiş olduğu cevaplar incelendiğinde; katılımcıların %24,4’ünün 
$(\mathrm{f}=10)$ rekabet edebilir duruma geliyorlar, \%19,5'inin $(\mathrm{f}=8)$ kendilerini geliştirmelerine ve büyümelerine katkı sağlıyor, $\% 17,1$ 'inin $(\mathrm{f}=7)$ hedef kitleye kolay ulaşım sağlayabiliyorlar, \%12,2'sinin ( $\mathrm{f}=5)$ güven vermiyorlar, $\% 9,8$ 'i ( $\mathrm{f}=4$ ) daha samimi olmaları ve kampanya, çekiliş gibi etkinliklerle tercih nedeni oluyorlar, \%7,3'ünün $(\mathrm{f}=1)$ rekabet ortamı yok, \%4,9'unun ( $\mathrm{f}=2$ ) pazar ağ1 geniş , \%4,9'unun ( $\mathrm{f}=2$ ) ulaşılabilir olmalarını sağlıyor görüşlerini bildirdiği görülmektedir.

Tablo 11. Instagram'da Paylaşımı Yapılan Fotoğrafın Altına Hangi Konularda Yorum Yazarsınız? Sorusuna Katılımcıların Vermiş Olduğu Cevapların Dağılımları

\begin{tabular}{lcc}
\hline Kodlar & $\mathrm{f}$ & $\%$ \\
\hline Ürün ile ilgili sorular & 11 & 26,8 \\
Yorum yazmıyorum & 12 & 29,3 \\
Memnuniyet ile ilgili yazılar & 5 & 12,2 \\
Aldığım ürünü tavsiye için & 10 & 24,4 \\
Fiyat bilgisi için & 3 & 7,3 \\
\hline Toplam & 41 & 100,0 \\
\hline
\end{tabular}

Tablo 11'de katılımciların Instagram sosyal ağından paylaşılan bir fotoğrafın altına hangi durumlarda yorum yazdıklarına ilişkin soruya vermiş olduğu cevaplar incelendiğinde; katılımcıların \%29,3'ünün $(\mathrm{f}=12)$ yorum yazmiyorum, \%26,8'inin ( $\mathrm{f}=11$ ) ürün ile ilgili sorular, \%24,4'ünün ( $\mathrm{f}=10$ ) aldığım ürünü tavsiye için, \%12,2'sinin $(\mathrm{f}=5)$ memnuniyet ile ilgili yazılar ve $\% 7,3$ 'ünün $(\mathrm{f}=3$ ) fiyat bilgisi için görüşlerini bildirdiği görülmektedir.

Tablo 12. Instagram Sosyal Ağından Alışveriş Tavsiyesinde Bulunmayı Çevrenize Hangi İletişim Şeklini Kullanarak Tavsiye Edersiniz? Sorusuna Katılımcıların Vermiş Olduğu Cevapların Dağılımları

\begin{tabular}{lcc}
\hline Kodlar & $\mathrm{f}$ & $\%$ \\
\hline Instagram (etiketleme, yorum, paylaşım) & 17 & 41,5 \\
Ağızdan ağıza & 12 & 29,3 \\
Facebook veya WhatsApp & 5 & 12,2 \\
Tavsiyede bulunmam & 7 & 17,1 \\
\hline Toplam & 41 & 100,0 \\
\hline
\end{tabular}

Tablo 12'de katılımcıların Instagram sosyal ağı üzerinden yaptıkları alışveriş deneyimlerine istinaden tavsiyede bulunma yöntemlerine ilişkin soruya vermiş olduğu cevaplar incelendiğinde; katılımcıların \%41,5'inin (f=17) Instagram üzerinden (etiketleme, yorum, paylaşım), \%29,3'ünün $(\mathrm{f}=12)$ ağızdan ağıza, \%17,1'inin ( $\mathrm{f}=7)$ tavsiyede bulunmam ve $\% 12,2$ 'sinin $(\mathrm{f}=5)$ Facebook veya WhatsApp üzerinden görüşlerini bildirdiği görülmektedir.

Tablo 13. Instagram İle Alışverişin Olumlu Yönleri Nelerdir? Sorusuna Katılımcıların Vermiş Olduğu Cevapların Dağılımları

\begin{tabular}{lcc}
\hline Kodlar & $\mathrm{f}$ & $\%$ \\
\hline Piyasaya göre uygun fiyat olması & 5 & 12,2 \\
Ürün çeşitliliğinin fazla olması & 8 & 19,5 \\
Ürün karş1laştırması yapılması & 3 & 7,3 \\
Hızlı ve kolay alışveriş yapılabilmesi & 12 & 29,3 \\
Trend ürünlerin yer alması & 1 & 2,4 \\
Tüketici tecrübelerinin yer alması & 2 & 4,9 \\
İletişimin kolay olması & 4 & 9,8 \\
Olumlu yanı yok & 5 & 12,2 \\
Görüş bildirmeyen & 1 & 2,4 \\
\hline Toplam & 41 & 100,0 \\
\hline
\end{tabular}

Tablo 13'de katılımcıların Instagram sosyal ağ1 üzerinden yapılan pazarlama faaliyetlerinin olumlu yönlerine ilişkin soruya vermiș olduğu cevaplar incelendiğinde; katılımcıların \%29,3'ünün ( $\mathrm{f}=12$ ) hızlı ve kolay alışveriş yapılabilmesi, $\% 19,5$ 'inin $(\mathrm{f}=8)$ ürün çeşitliliğinin fazla olması, $\% 12,2$ 'sinin (f=5) piyasaya göre uygun fiyat olması, $\% 12,2$ 'sinin ( $\mathrm{f}=5$ ) olumlu yanı olmadığ 1 , \%9,8'inin ( $\mathrm{f}=4$ ) iletişimin kolay olmas1, $\% 7,3$ 'ünün $(\mathrm{f}=3)$ ürün karşılaştırması yapılması, \%4,9'unun (f=2) tüketici tecrübelerinin yer almas1 ve $\% 2,4$ 'ünün $(\mathrm{f}=1)$ trend ürünlerin yer alması görüşlerini bildirdiği görülmektedir.

Tablo 14. Instagram ile alı̧̧verişin olumsuz yönleri nelerdir? Sorusuna Katılımcıların Vermiş Olduğu Cevapların Dağılımları

\begin{tabular}{lcc}
\hline Kodlar & $\mathrm{f}$ & $\%$ \\
\hline Sunulan ürünle gelen ürünün birebir aynı olmamas1 & 12 & 29,3 \\
Belirtilenden düşük kalitede ürün gelmesi & 1 & 2,4 \\
Ürünle ilgili net bilgi verilmemesi & 1 & 2,4 \\
İade ve değişim sorunları & 3 & 7,3 \\
Kargo ücreti & 2 & 4,9 \\
Yanıltıc1 yorumların olması & 1 & 2,4 \\
Güvenli olmaması ve dolandırıcılık & 10 & 24,4 \\
Olumsuz bir yanı yok & 5 & 12,2 \\
Ürünü denemeden almak & 4 & 9,8 \\
Kargo şirketi ile ilgili problemler & 1 & 2,4 \\
Pahalı olmas1 & 1 & 2,4 \\
\hline Toplam & 41 & 100,0 \\
\hline
\end{tabular}

Tablo 14'de katılımcıların Instagram sosyal ağ1 üzerinden yapılan pazarlama faaliyetlerinin olumsuz yönlerine ilişkin soruya vermiş olduğu cevaplar incelendiğinde; katılımcıların \%29,3'ünün ( $\mathrm{f}=12$ ) sunulan ürünle gelen ürünün birebir aynı olmaması, \%24,4'ünün $(\mathrm{f}=10)$ güvenli olmaması ve dolandırıcılık, \%12,2'sinin $(\mathrm{f}=5)$ olumsuz bir yanı olmadığ 1 , \%9,8'inin ( $\mathrm{f}=4$ ) ürünü denemeden almak, \%7,3'ünün ( $\mathrm{f}=3$ ) iade ve değișim sorunları, \%4,9'unun $(\mathrm{f}=2)$ kargo ücreti, $\% 2,4$ 'ünün $(\mathrm{f}=1)$ belirtilenden düşük kalitede ürün gelmesi, $\% 2,4$ 'ünün $(\mathrm{f}=1)$ ürünle ilgili net bilgi verilmemesi, $\% 2,4$ 'ünün ( $\mathrm{f}=1)$ yanıltıcı yorumların olması, \%2,4'ünün $(\mathrm{f}=1)$ kargo şirketi ile ilgili problemler ve $\% 2,4$ 'ünün $(\mathrm{f}=1)$ pahalı olması görüşlerini bildirdiği görülmektedir.

Tablo 15. Instagram sosyal ağından alışveriş yaparken olmasını istediğiniz veya memnun olmadığınız şeyler nelerdir? Sorusuna Katılımcıların Vermiş Olduğu Cevapların Dağılımları

\begin{tabular}{lcc}
\hline Kodlar & f & $\%$ \\
\hline Ürün şeffaf kapta gönderilebilir & 2 & 4,9 \\
Gelen ürünün farklı özellikte olması & 4 & 9,8 \\
Ödeme yöntemi (kapıda ve kredi kartı ödemesi & 4 & 9,8 \\
olmaması) & 1 & 2,4 \\
Bazı sayfalarda ürün fiyatlarının yazmaması & 10 & 24,4 \\
Memnun olmadığım bir durum yok & 4 & 9,8 \\
İletişim kolaylığı olmalı & 4 & 9,8 \\
Kargo sorunları & 4 & 9,8 \\
Ürünle ilgili gerçek bilgiler yazılmalı & 8 & 19,5 \\
Güvenli olmalı ve dolandırıcılı önleyici çalışmalar & 8 & \\
yapılmalı & 41 & 100,0 \\
\hline Toplam & & \\
\hline
\end{tabular}

Tablo 15'de katılımcıların Instagram sosyal ağından alışveriş yaparken olmasını istediği veya memnun olmadığı durumlara ilişkin soruya vermiş olduğu cevaplar incelendiğinde; katılımcıların \%24,4'ünün (f=10) memnun olmadığım bir durum yok, \%19,5'inin ( $\mathrm{f}=8)$ güvenli olmalı ve dolandırıcılığı önleyici çalışmalar yapılmalı, \%9,8'inin ( $\mathrm{f}=4)$ gelen ürünün farklı özellikte olması, \%9, 8 'inin $(\mathrm{f}=4)$ ödeme yöntemleri düzenlenmeli (kapıda ve kredi kartı 
ödemesi olmaması), \%9,8'inin (f=4) iletişim kolaylığ olmalı, \%9,8'inin (f=4) kargo sorunları giderilmeli, $\% 9,8$ 'inin $(\mathrm{f}=4)$ ürünle ilgili gerçek bilgiler yazılmalı, $\% 4,9$ 'unun $(\mathrm{f}=2)$ ürün şeffaf kapta gönderilebilir ve $\% 2,4$ 'ünün (f=1) bazı sayfalarda ürün fiyatlarının yazmaması görüşlerini bildirdiği görülmektedir.

\section{Sonuç ve Öneriler}

Instagram sosyal ağının pazarlama faaliyetlerine olan etkilerini incelemeyi amaçlayan araştırmada Instagram sosyal ağını kullanan katılımcıların 3-5 yıl arası ve ortalama 3 yılın üzerinde kullanım sağladıkları, gün içinde Instagram sayfasını kontrol etme sıklıklarında 6-10 kez kontrol edenlerin oranının yüksek olduğu sonuçlarına ulaşılmıştır. $\mathrm{Bu}$ bulgu Yaşa Özeltürkay, Bozyiğit ve Gülmez (2017) tarafindan yapılan araştırma bulgularıyla paralellik göstermektedir. Instagram kullanıcılarının kontrol etme sıklıkları arttıkça, işletmelerin yapmış olduğu paylaşım ve reklamları kullanıcıların görme oranları artacak ve müşteri ilgisini çekici olabilecektir.

Katılımcıların Instagram sosyal ağında yer alan işletme sayfalarını takip etme nedenlerine ilişkin bulgu sonuçları incelendiğinde sırayla; görsel ve paylaşımları ilgi çekici olduğu için, ihtiyaçlarımı karşıladığı ve ilgi alanımda olduğu için, ürünleri takip etmek ve satın almak için, ürün hakkında bilgi edinmek için, ekonomik ürünler olduğu için ve güvenilir bir alışveriş sayfası olduğu için tercih ettikleri sonucuna ulaşılmıştır. $\mathrm{Bu}$ bulgu alanda yapılan bazı çalışmalar ile benzerlik göstermektedir (Dariswan ve Indriani, 2014; Iconosquare, 2015; Yaşa Özeltürkay, Bozyiğit ve Gülmez, 2017). İşletmeler pazarlama faaliyetini geliştirmek ve rekabet edebilir konuma gelmek için görsel ve ilgi çekici paylaşımlar yapabilir, paylaşımlarda ürün bilgileri tam yazılabilir ve ürün çeşitliliği sağlayarak tüketicilerin ilgisini çeken ürünler ile faaliyetlerini geliştirebilirler.

Katılımcıların Instagram sosyal ağından hangi ürünleri satın aldıklarına ilişkin bulgu sonuçları incelendiğinde sırayla; giyim ürünlerini, ayakkabı, takı, hediyelik ve süs eşyası, elektronik ve kozmetik ürün aldıkları sonucuna ulaşılmıştır. Bosca (2015) tarafindan yapılan araştırmada katılımcıların Instagramdan en çok satın aldıkları ürünlerin elbise, takı ürünleri ve ayakkabı olduğu ve Yaşa Özeltürkay, Bozyiğit ve Gülmez (2017) tarafindan yapılan araştırmada genellikle kıyafet, ayakkabı, takı ve saat satın aldıkları sonucuna ulaşılmıştır. Araştırmalarda çıkan bulgu sonuçları ile bu araştırmada çıkan bulgu sonuçlarının aynı doğrultuda olduğu görülmektedir. Instagramda pazarlama faaliyeleri gösteren işletmeler bu alana yönelik satışlarını arttırabilir veya ürün çeşitliliği sağlayarak müşteri kitlesini genişletebilir.

Katılımcıların Instagram sosyal ağı üzerinden ürün alma isteklerini etkileyen etkenlere ilişkin bulgu sonuçları incelendiğinde sırayla; yüksek oranda yorumların etkili olduğu, takipçi sayısı ve beğeni sayısının da ürün satın alma isteklerinde etkili olduğu, görselliği yüksek paylaşımlarının olması satın alma isteklerine olumlu katkısı olduğu ve az sayıdaki katılımcı görüşüne göre herhangi bir etkisinin olmadığı sonuçlarına ulaşılmıştır. İşletmeler pazarladıkları ürünler hakkındaki müşteri memnuniyetlerini diğer kullanıcılarında göreceği şekilde paylaşılmasını sağlar ve müşteri memnuniyetine göre pazarlama ve satış yaptığı ürünleri düzenler ise olumlu yorum ve beğeni alarak satışlarını arttırabilecektir.

Araştırmaya katılan katılımcıların Instagram sosyal ağ üzerinden ürün alma nedenlerine ilişkin bulgu sonuçları incelendiğinde sırayla; fiyatı uygun ürünlerin yer alması, takipçiler tarafindan ürünün etkileyici bulunması, ürün çeşitliliğinin olması, alışverişin kolay olması, satıcıya güven duyurulması ve kapıda ödeme kolaylığının olması sonucuna ulaşılmıştır. Kullanıcılar uygun fiyatlı ürünleri ilk olarak tercih etmekte, aradığ 1 ürünü fiziksel ortamda bulamaması ve farklı ürünlere erişememesinden, yorulmadan zaman ve mekân fark etmeksizin takip ettiği ya da aradığı ürün hakkında bilgi alma, satın alma işlemlerini yapabilmesinden ve aldığı ürünün kapıda ödeme kolaylığı olmasından dolayı bu ortamdan alışveriş yapmayı tercih ettiği söylenebilir.

Instagram sosyal ağının pazarlama üzerindeki etkilerine ilişkin bulgu sonuçları incelendiğinde sırayla; etkili ürün tanıtımları yapılabildiği, kolay ve hızlı alışveriş ortamı sunduğu, geniş kitlelere ulaşılabildiği, sosyal ağ üzerindeki reklamların çok etkili olduğu, ürün çeşitliliği sağladığı sonucuna ulaşılmıştır. İşletmelerin satışını yaptığı ürünler için müşteri ilgisini çeken, reklamlar ve paylaşımlar ile geniş müşteri kitlesine ulaşılabilirliği sağladığı, fiziksel ortamda bulamadığı ürünleri bu ortamda bulabildiği, kullanıcıların zahmetsiz ve hızlı bir şekilde alışveriş sürecini gerçekleştirebildiği söylenebilir.

Katılımcıların Instagram sosyal ağı üzerinden küçük işletmelerin pazarlama faaliyetlerine ilişkin bulgu sonuçları incelendiğinde sırayla; rekabet edebilir duruma gelebildikleri, kendilerini geliştirmelerine ve büyümelerine katkı sağladığı, hedef kitleye kolay ulaşım sağlayabildikleri, daha samimi olmaları, kampanya, çekiliş gibi etkinliklerle tercih nedeni oldukları, pazar ağlarının geniş olduğu ve ulaşılabilir oldukları olumlu sonuçlarına ulaş1lırken, düşük orandaki katılımc1 görüşüne istinaden ise güven vermedikleri ve rekabet ortamı olmadığı sonuçlarına ulaşılmıştır.

Katılımcıların Instagram'da paylaşılan bir fotoğrafın altına hangi durumlarda yorum yazdıklarına ilişkin bulgu sonuçları incelendiğinde sırayla; yorum yazmadıkları, ürün ile ilgili sorular için yorum yazdıkları, ürünü tavsiye etmek için yazdıkları, memnuniyet ve ürün fiyatı öğrenmek için yazdıkları sonuçlarına ulaşılmıştır.

Katılımcıların Instagram sosyal ağı üzerinden yaptıkları alışveriş deneyimlerini tavsiye etmelerine ilişkin bulgu sonuçları incelendiğinde; yüksek oranda Instagram üzerinden, etiketleme, yorum ve paylaşımlar ile, ağızdan ağıza ve Facebook veya WhatsApp üzerinden tavsiyede bulundukları sonucuna ulaşılmıştır. Belli orandaki katılımcı ise tavsiyede bulunmam görüşünde bulunmuştur. Yaşa Özeltürkay, Bozyiğit ve Gülmez (2017) tarafından yapılan çalışma sonucunda katılımcıların büyük çoğunluğunun Instagram'dan alışveriş yapmayı arkadaşlarına tavsiye ettiği ve bunu Instagram, ağızdan ağıza iletişim, Facebook ve internet vasıtasıyla yaptığı benzer sonuçlarına ulaşılmıştır.

Katılımcıların Instagram sosyal ağı üzerinden yapılan pazarlama faaliyetlerinin olumlu yönlerine ilişkin bulgu sonuçları incelendiğinde sırayla; hızlı ve kolay alışveriş yapılabilmesi, ürün çeşitliliğinin fazla olması, piyasaya göre uygun fiyatlı ürünlerin olması, iletişimin kolay olması, ürün 
karşılaştırması yapılabilmesi, tüketici tecrübelerinin ve trend ürünlerin yer alması sonuçlarına ulaşılırken çok az katılımcı görüşüne istinaden olumlu yanı olmadığı sonuçlarına ulaşılmıştır.

Katılımcıların Instagram sosyal ağı üzerinden yapılan pazarlama faaliyetlerinin olumsuz yönlerine ilişkin bulgu sonuçları incelendiğinde sırayla; sunulan ürünle gelen ürünün birebir aynı olmaması, güvenli olmaması ve dolandırıcılığın olması, ürünü denemeden almak, iade ve değişim sorunları, kargo ücreti, belirtilenden düşük kalitede ürün gelmesi, ürünle ilgili net bilgi verilmemesi, yanıltıcı yorumların olması, kargo şirketi ile ilgili problemlerin olması, pahalı olması sonuçlarına ulaşılırken az sayıdaki katılımcı görüşüne istinaden olumsuz bir yanı olmadığ 1 sonuçlarına ulaşılmıştır.

Katılımcıların Instagram sosyal ağı ile alışveriş yaparken olmasını istediği veya memnun olmadığı durumlara ilişkin bulgu sonuçları incelendiğinde sırayla; kullanıcıların memnun olmadığım bir durum yok, güvenli olmalı ve dolandırıcılığı önleyici çalışmalar yapılmalı, sipariş edilen ürün ve gelen ürünün farklı özellikte olmamasına dikkat edilmeli, ödeme yöntemleri düzenlenmeli (kapıda ve kredi kartı ödemesi olmaması), iletişim kolaylığı olmalı, kargo sorunları giderilmeli, ürünle ilgili gerçek bilgiler yazılmalı, ürün şeffaf kapta gönderilmeli ve bazı sayfalarda ürün fiyatları eksiksiz yazılmalı sonuçlarına ulaşılmıştır. Bu bulgu Yaşa Özeltürkay, Bozyiğit ve Gülmez (2017) tarafından yapılan araştırma bulgularıyla benzerlik göstermektedir. İşletmelerin pazarlama faaliyetlerinde güvenilirliğini artırıcı çalışmalar yapmaları, satışı yapılan ürünlerin aynı özellikte yollanması, ödeme yöntemlerinde farklı seçenekler sunabilir durumda olmaları, doğru iletişim kurabilme noktasında kendilerini geliştirmeleri, sorunlara yönelik önlem ve uygulamaları almaları sonucu alana daha fazla katkı sağlayacağı görülmektedir.

Araştırma sonuçları irdelendiğinde işletmelerin müşteri ilgi, beklenti ve isteklerine göre pazarlama faaliyetlerini gerçekleştirdiklerinde, Instagram üzerinden pazarlama faaliyetlerinin çok olumlu olduğu, küçük işlemlerin rekabet edebilir konuma geldiği, reklam ve ürün tanıtımlarında büyük faydalarının olduğu, sosyal medya pazarlamasına yönelik işletmelerin kendilerini geliştirmeleri, grafik tasarım, video, Instagram ve sosyal ağların nitelikli ve etkin kullanımını sağlamaları, büyük pazarlara ulaşabilme ve işletme faaliyetlerini geliştirmelerinde büyük katkıları olacağı sonuçları elde edilmiştir.

Araştırmanın amaçları doğrultusunda elde edilen bulgu sonuçlarına istinaden şu önerilerde bulunulabilir:

(i) Çalışma farklı yöntemler kullanılarak uygulanabilir ve derinlemesine incelenebilir.

(ii) Araştırma farklı bölgelerde oturan tüketiciler ile tekrar edilebilir,

(iii) Çalışma farklı yöntemler uygulanarak daha çok kişiye ulaşabilir ve sonuçları karılaştırılarak alana katk1 sağlayabilir.

(iv) Instagram üzerinden pazarlama faaliyetlerini gerçekleştiren satıcıların görüşleri alınarak yeni bir çalışma yapılabilir ve bu araştırma sonuçları ile karşılaştırılarak alana katkı sağlayabilir.

\section{Kaynakça}

Akar, E. (2010). Sosyal Medya Pazarlamasi, Sosyal Webde Pazarlama Stratejileri.Ankara: Efil Yayınevi.

Albay, M. N. (2010). Geleneksel Pazarlamadan Yeni Pazarlama Yaklaşımlarına Geçiş Süreci. Süleyman Demirel Üniversitesi İktisadi ve İdari Bilimler Fakültesi Dergisi, 15(2), 213-235.

Ashley, C., \& Tuten, T. (2015). Creative strategies in social media marketing: An exploratory study of branded social content and consumer engagement. Psychology \& Marketing, 32(1), 15-27.

Balcı, A. (2005). Sosyal Bilimlerde Araştırma: Yöntem Teknik ve Illkeler. Ankara: Pegem Akademi.

Bartlett-Bragg, A. (2006). Reflections On Pedagogy: Reframing Practice To Foster Informal Learning With Social Software. Retrieved, 1, 2014.

Bosca, S. (2015). Instagram'da En Çok Satılan Ürünler Neler?. (Erişim: 15.12.2015), http://www.salihbosca.com/ instagramda-en-cok-satilanurunler-neler/

Bose, R. (2002). Customer Relationship Management: key components for IT success. Industrial Management and Data Systems, 102(2), 89-97.

Burgaz, A. (2014). Halkla Ilişkilerde Sosyal Medya Kullanımı Ve Sosyal Medyada Pazarlama (Bizce Tanıtım Halkla İlişkiler Ajansı ve Sesli Harfler Dijital Reklam Ajansı Örneği). Yüksek Lisans Tezi. İstanbul: İstanbul Aydın Üniversitesi.

Büyüköztürk, Ş. (2005). Sosyal Bilimler Iç̧in Veri Analizi El Kitabı. Ankara: Pegema Yayıncılık.

Çetinkaya, A., \& Özdemir, Z. (2014). Sosyal ağların pazarlama disiplinleri içinde kullanımı: Instagram üzerine bir inceleme. İçinde: "Dijital İletişim Etkisi" Uluslararası Akademik Konferans Bildiri Kitabı, Can Bilgili (Ed.), 581-641, 16-17 Ekim, Istanbul, Turkiye.

Dariswan, P.P., \& Indriani, M.T.D. (2014). Consumers' Attitude Toward Shopping Through Instagram Social Media, Proceedings of 7th Asia-Pacific Business Research Conference 25 - 26 August 2014, Bayview Hotel, Singapore, 1-16.

Dijkmans, C., Kerkhof, P., \& Beukeboom, C. J. (2015). A stage to engage: Social media use and corporate reputation. Tourism Management, 47, 58-67.

Ferah, A.B. (2013). Instagram'ın İlk Reklam Vereni Michael Kors Oldu. (Erişim: 20 Ocak 2016), https://webrazzi.com/2013/11/04/instagramin-ilkreklam-vereni-michael-kors-oldu/

Goor, M. (2012). Instamarketing: A Content Analysis into Marketing on Instagram. Master's Programme Communication Science. Master's Thesis. Amsterdam: Amsterdam University.

Hazar, M. (2011). Sosyal Medya Bağımlılığı - Bir Alan Çalışması. Iletişim Kuram ve Araştırma Dergisi, 32.

Iconosquare (2015). Why Instagram accounts can be viewed on Iconosquare. (Accessed January 20, 2016), https://ic- 
onosquare.desk.com/customer/en/portal/articles/150832 1-why-instagram-accounts-can-be-viewed-oniconosquare

Kaplan, A. M., \& Haenlein, M. (2010). Users of the world, unite! The challenges and opportunities of Social Media. Business horizons, 53(1), 59-68.

Kara Y. ve Coşkun, A. (2012). Sosyal Ağların Pazarlama Aracı Olarak Kullanımı: Tür-kiye'deki Hazır Giyim Firmaları Örneği. Afyon Kocatepe Üniversitesi İ̈BF Dergisi, C.XIV, S. II, ss.73-90.

Köksal, Y. ve Özdemir, Ş. (2013). Bir İletişim Aracı Olarak Sosyal Medya'nın Tutundurma Karması İçerisindeki Yeri Üzerine Bir İnceleme. Suleyman Demirel University Journal of Faculty of Economics \& Administrative Sciences, 18 (1).

Köksal, Y., \& Özdemir, Ş. (2013). Bir iletişim aracı olarak sosyal medya'nın tutundurma karması içerisindeki yeri üzerine bir inceleme. Süleyman Demirel Üniversitesi İktisadi ve İdari Bilimler Fakültesi Dergisi, 18(1), 323 337.

Kuş, E. (2003). Nicel-Nitel Araştırma Teknikleri. Ankara: An1.

Kutluğ, N. (2014). Hafif ve Akışkan. (Erişim: 25.12.2015), http://www.nesetkutlug.com/blog/2014/9/hafif-veakışkan

Özdemir, Z., \& Çetinkaya, A. (2014). Müşteri Etkileşimi Yaratma Açısından Sosyal Medya: Türkiye'deki Hazır Giyim Lovemark'ları Üzerine Bir İnceleme. (ed. Y. Budak ve B. Küçüksaraç), I. Uluslararası İletişim Bilimi ve Medya Araştırmaları Kongresi bildiriler kitabı II içinde (ss.81-101). 12-15 Mayıs. Kocaeli: Kocaeli Üniversitesi.

Peelan, E., \& Beltman, R. (2013). Customer Relationship Management. Pearson.

Sevinç, S. S. (2015). Pazarlama iletişiminde sosyal medya. Optimist.

Solomon, M. R. (2013). Consumer Behavior: Buying, Having and Being. Prentice Hall, Inc.

Tiryakioglu, F., \& Erzurum, F. (2011). Use of social networks as an education tool. Contemporary Educational Technology, 2(2).

Türnüklü, A. (2000). Eğitimbilim araştırmalarında etkin olarak kullanılabilecek nitel bir araştırma tekniği: Görüşme. Kuram ve Uygulamada Eğitim Yönetimi Dergisi, (24), 543-559.

Vural, Z., \& Bat, M. (2010). Yeni Bir İletişim Ortami Olarak Sosyal Medya: Ege Üniversitesi İletişim Fakültesine Yönelik Bir Araştirma. Journal of Yasar University, $5(20)$.

Wally, E., \& Koshy, S. (2014). The Use Of Instagram As A Marketing Tool By Emirati Female Entrepreneurs: An Exploratory Study. In: 29th International Business Research Conference, World Business Institute Australia, Australia, 1-19.
Weber, L. (2007). Marketing to the social web: How digital customer communities build your business. Hoboken, NJ: John Wiley \& Sons.

Weber, L. (2009). Twitter Marketing: Promote Yourself and Your Business on Earth's Hottest. USA: Weber Books.

Xiang, Z., \& Gretzel, U. (2010). Role of social media in online travel information search. Tourism Management, 31(2), 179-188.

Yıldırım, A., \& Şimşek, H. (2005). Sosyal Bilimlerde Nitel Araştırma Yöntemleri. Ankara: Seçkin Yayıncılık.

Y1lmazsoy, B., \& Kahraman, M. (2017). Üniversite öğrencilerinin sosyal medya bağımlılığı ile sosyal medyayı eğitsel amaçlı kullanımları arasındaki ilişkinin incelenmesi: Facebook örneği. Journal of Instructional Technologies \& Teacher Education, 6(1), 9-20. 